\title{
Transpiration rate response to water deficit during vegetative and reproductive phases of upland rice cultivars
}

\author{
Alexandre Bryan Heinemann*; Luís Fernando Stone; Nand Kumar Fageria \\ Embrapa Arroz e Feijão, C.P. 179 - 75375-000 - Santo Antônio de Goiás, GO - Brasil. \\ *Corresponding author < alexbh@cnpaf.embrapa.br>
}

\begin{abstract}
Water deficit is one of the most important abiotic stress limiting upland rice yield in the "Cerrado" region of Brazil. Selecting drought tolerant cultivars is an important strategy to overcome this constraint. Two greenhouse experiments were conducted at Santo Antônio de Goiás, state of Goiás, Brazil, to compare the response of normalized transpiration rate (NTR) of three modern (BRS Primavera, BRSMG Curinga and BRS Soberana) and one traditional (Douradão) upland rice cultivars to soil water deficit during the vegetative and reproductive growth stages. This information will support breeding strategies to improve rice yield in a drought-prone target population environments (TPE) in Brazil. NTR and the total fraction of transpirable soil water (FTSW) were calculated, plotted and adjusted according to a sigmoid non-linear model. The $p$ factor, defined as the fraction of available soil water that can be removed from the root zone before water deficit occurs, was calculated by assuming that it occurs when NTR is equal to 0.95 . Modern cultivars had a higher value of $p$ for the reproductive phase than for the vegetative phase. In addition, these cultivars are better adapted to express their potential yield in regions with low intensity and occurrence of water stress and the traditional cultivar is enable to better support adverse conditions of water stress. It can be concluded that there is need to precisely characterize drought patterns in TPEs. This information can focus the breeding program to improve drought tolerance in modern upland rice cultivars.
\end{abstract}

Key words: Oryza sativa, available soil water, dry spells, fraction of soil water transpiration

\section{Resposta da taxa de transpiração ao déficit hídrico nas fases vegetativa e reprodutiva de cultivares de arroz de terras altas}

\begin{abstract}
RESUMO: A deficiência hídrica é considerada um dos mais importantes estresses abióticos que limitam a produtividade do arroz de terras altas no Cerrado. Uma estratégia para minimizar os efeitos da estiagem durante o período chuvoso na produtividade do arroz de terras altas é o uso de cultivares com mecanismos de tolerância à seca. Foram conduzidos dois experimentos em casa de vegetação em Santo Antônio de Goiás, GO, Brasil, para avaliar a resposta da taxa de transpiração normatizada (NTR) de três cultivares modernas (BRS Primavera, BRSMG Curinga e BRS Soberana) e uma tradicional (Douradão) de arroz de terras altas ao déficit hídrico no solo nas fases vegetativa e reprodutiva. Essa informação visa apoiar estratégias de melhoramento para incrementar a produtividade do arroz em ambientes para população alvo (TPEs) propensos à seca no Brasil. Foram calculadas a NTR e a fração da água do solo transpirável (FTSW) e esses dados foram ajustados segundo um modelo sigmoidal não linear. O fator $p$, definido como a fração de água disponível no solo que pode ser retirada da zona radicular antes de ocorrer deficiência hídrica, foi calculado assumindo-se que ele ocorre quando NTR for igual a 0,95. Para os cultivares modernos foram observados valores maiores do fator $p$ na fase reprodutiva que na vegetativa. Esses cultivares expressam melhor seu rendimento potencial em regiões com baixa intensidade e ocorrência de deficiência hídrica, e o cultivar tradicional está habilitado a melhor suportar condições adversas de deficiência hídrica. Há necessidade de caracterizar precisamente os padrões de seca nas TPEs. Essa informação pode direcionar o programa de melhoramento para incrementar a tolerância à deficiência hídrica nas cultivares modernas de arroz de terras altas.

Palavras-chave: Oryza sativa, água disponível no solo, veranicos, fração da água do solo transpirável
\end{abstract}

\section{Introduction}

The use of drought tolerant cultivars is the most promising strategy to minimize the effects of water deficit on upland rice growth and productivity during the rainy season. The use of highly drought-tolerant donors as parents in crosses with high yielding but susceptible varieties resulted in a higher frequency of genotypes combining high-yield potential with drought tolerance (Kumar et al., 2008). However, it is complex to select these cultivars, as yield under drought is the result of many physiological processes involved in the carbon and water balances of the crop (Turner et al., 2000). Under drought, the leaf gas exchange of plants is reduced and this leads to lower biomass accumulation and grain yield. Previous reports on several crops show genotypic differences in how leaf gas exchange responds to water stress, with certain genotypes being capable of sustaining plant transpiration until the soil becomes fairly dry, whereas others react with a decline in transpiration 
when the soil is still relatively wet. This has been observed over a wide range of crops, maize (Ray and Sinclair, 1997), soybean (Vadez and Sinclair, 2001; Hufstetler et al., 2007), groundnut (Bhatnagar-Mathur et al., 2007), rice (Serraj et al., 2008) and pearl millet (Kholová et al., 2010). This also supported the robustness of using the fraction of transpirable soil water (FTSW) as a stress covariable in drought studies (Serraj et al., 2009). Therefore, the soil moisture threshold, the factor of FTSW where transpiration declines is extremely useful to understand and forecast the genotypic behavior in face of water deficit (Sadras and Milroy, 1996; Ray and Sinclair, 1997). Rice genotypes can respond differently to drought as a function of the phenological development (Pantuwan et al., 2002; Fisher and Fukai, 2003). This study aimed to compare the response of the transpiration rate of four upland rice cultivars to soil water deficit during the vegetative and reproductive growth stages to support breeding strategies to improve rice yield in a drought-prone target population environment in Brazil.

\section{Material and Methods}

Two greenhouse experiments, with two sowing dates, were conducted at Santo Antônio de Goiás, state of Goiás, Brazil, during 2008 to evaluate the response of four upland rice cultivars to soil water deficit at different phenological phases. The local climate characterization is illustrated in Figure 1. The soil was an Oxisol with the following chemical characteristics: $\mathrm{pH}$ in water $4.9, \mathrm{Ca} 1.8$ mmol $\mathrm{dm}^{-3}, \mathrm{Mg} 1.1 \mathrm{mmol}_{\mathrm{c}} \mathrm{dm}^{-3}, \mathrm{Al} 2 \mathrm{mmol}_{\mathrm{c}} \mathrm{dm}^{-3}, \mathrm{H}+\mathrm{Al}$ $40.6 \mathrm{mmol}_{\mathrm{c}} \mathrm{dm}^{-3}$, P $0.6 \mathrm{mg} \mathrm{dm}^{-3}, \mathrm{~K} 12 \mathrm{mg} \mathrm{dm}^{-3}, \mathrm{Cu} 1.7 \mathrm{mg}$ $\mathrm{dm}^{-3}, \mathrm{Zn} 0.6 \mathrm{mg} \mathrm{dm}^{-3}$, Fe $34 \mathrm{mg} \mathrm{dm}^{-3}$, Mn $2 \mathrm{mg} \mathrm{dm}^{-3}$, and organic matter $12 \mathrm{~g} \mathrm{dm}^{-3}$. The experiments were conducted in plastic pots. Each pot received $12 \mathrm{~g}$ of dolomitic lime, $158 \mathrm{mg} \mathrm{kg}^{-1} \mathrm{~K}, 69 \mathrm{mg} \mathrm{kg}^{-1} \mathrm{P}, 400 \mathrm{mg} \mathrm{kg}^{-1} \mathrm{~N}, 20 \mathrm{mg} \mathrm{kg}-$ ${ }^{1} \mathrm{Zn}, 5 \mathrm{mg} \mathrm{kg}^{-1} \mathrm{Cu}, 1 \mathrm{mg} \mathrm{kg}^{-1} \mathrm{~B}$, and $0.5 \mathrm{mg} \mathrm{kg}^{-1} \mathrm{Mo}$. One third of $\mathrm{N}$ was applied at sowing and the remaining was top-dressed at two equal rates at the beginning of tillering, V4 stage of the Counce et al. (2000) scale, and at panicle

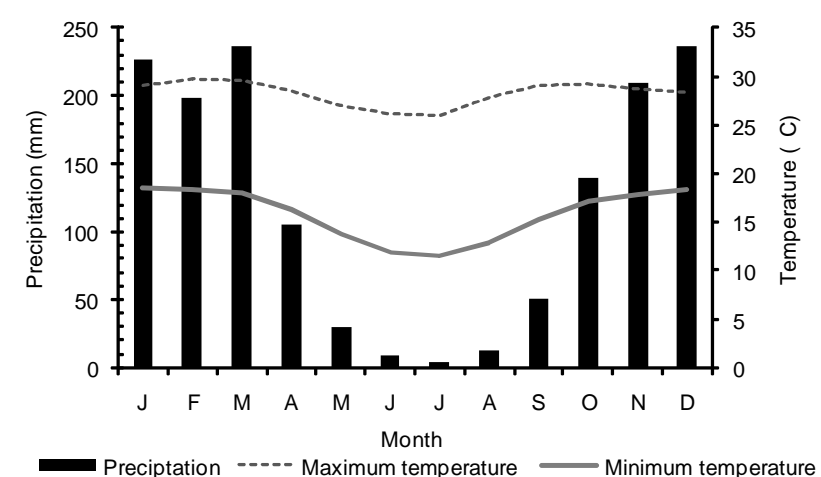

Source: Heinemann et al. (2007).

Figure 1 - Monthly averages for precipitation, maximum and minimum temperatures for Santo Antônio de Goiás, GO. differentiation (PD), R1 stage of Counce et al. (2000) scale. Four upland rice genotypes (BRS Primavera, BRSMG Curinga, BRS Soberana, and Douradão) were chosen due to their difference in physiological traits (Heinemann et al., 2009) as well as due to their use as parental lines in Embrapa's breeding programs (Breseghello et al., 2008). The BRS Primavera, BRSMG Curinga and BRS Soberana are considered modern cultivars and Douradão an old traditional cultivar. They differ in number of leaves in the main stem and consequently in the development cycle, BRSMG Curinga being the latest (medium cycle) and BRS Soberana the earliest cultivar (early cycle). The Haun index for the four cultivars is described in detail in Heinemann et al. (2009). The observed data used in this study come from two experiments with sowing dates in $27 / 08 / 2008$ and $10 / 17 / 2008$. In this way it was possible to obtain a range of environmental conditions in order to minimize the extreme effects of vapor pressure deficit in the transpiration rates, which could affect the normalized transpiration rate (NTR) response to the soil drying process (Sinclair et al., 2008). The experimental design was a completely randomized split-plot. The main plot was the water treatment (water stress, WS and no water stress, NWS) and cultivars were in the subplots. Treatments were replicated six times.

For each planting date, two experiments were conducted and named vegetative $(\mathrm{V})$ and reproductive $(\mathrm{R})$. For each of them 48 pots were filled with $7 \mathrm{~kg}$ of dry soil. After germination, plant population was thinned to one plant per pot at the stage V5 and R0, according to Counce et al. (2000), for experiments V and R, respectively. In the $\mathrm{V}$ experiment, plants were grown under potential condition (no water and nutrient deficit) until leaf number 5 on the main stem emerged. At this plant stage soil water evaporation losses were minimized by covering the pots with a plastic film leaving out only the plant. Half of the pots, considered as control (24 pots), were kept daily well watered (NWS treatment). The other set of pots (24) did not receive water anymore (WS treatment). All pots were weighted daily (three times per day) to estimate transpiration losses. For the $\mathrm{R}$ experiment, the same procedure was used, however, plants were grown under potential conditions until RO, beginning of panicle initiation (Counce et al., 2000). The pots were covered with plastic film when each cultivar reached the RO stage. This phase has the highest probability of water stress occurrence in the Goiás State for upland rice (Heinemann et al., 2008).

Water content data of the experiment were expressed as a function of the fraction of transpirable soil water (FTSW). The applied methodology was based on Wahbi and Sinclair (2007). Total transpirable soil water (TTSW) was the difference between the pot weight at $100 \%$ of the water holding capacity (pot weight about $8.9 \mathrm{~kg}$ ) and its weight when the transpiration rate of the stressed plants (WS treatment) was less than 10\% of that of the control plants (NWS treatment) (pot weight about 7.3 $\mathrm{kg})$. The daily value of FTSW was estimated as the ra- 
tio between the amount of water still remaining in the pot and TTSW:

$$
F T S W=\frac{W T_{n}-W T_{n+1}}{T T S W}
$$

where $W T_{n}-W T_{n+1}$ is the actual pot weight (amount of transpirable soil water in the pot) in the WS treatment, and $\mathrm{n}$ is the number of the weighing operation. The actual pot weight was obtained by weighting the pots daily during the drying cycle. The transpiration rate (TR) was calculated by dividing the transpiration of each individual plant of a given genotype from the WS treatment by the average of the NWS (control treatment) transpiration of that genotype. Secondly, the TR was normalized by dividing each TR value over time by the average of the TR value for the first two days of the experiment when there was still no water limitation in WS treatment. This second normalization resulted in the normalized transpiration rate (NTR), which accounted for the plant to plant variation in transpiration within each genotype. Transpiration was calculated just subtracting the covered pots from the WS treatment three times per day during the period of water deficit. No attempt was made to correct for the small increase in plant mass during the experiment, which would have resulted in a small error causing a small underestimate of the lower end point (Sinclair and Ludlow, 1986; Wahbi and Sinclair, 2007). The WS treatment finished when plant transpiration was $10 \%$ of the control treatment (NWS), assuming that under these conditions plants almost died.

Values of NTR and FTSW obtained during the drying experiments for each plant on each day were all combined to obtain the NTR response curve for each cultivar in each experiment as a function of FTSW. The response data were analyzed using a sigmoid non-linear model (eq. 2). This model was proposed by Muchow and Sinclair (1991) for drought studies in crop plants:

$$
N T R=\frac{1}{(1+a * \exp (-b * F T S W)}
$$

where, $a$ and $b$ are empiric parameters.

All regressions were calculated using the $\mathrm{R}$ software, v.2.9, nls function from NLME package ( $R$ Development Core Team, 2009). The empiric parameters $a$ and $b$ for both phases, vegetative and reproductive, for each cultivar were compared using an average test based on the confidence interval at $95 \%$ of probability using the function confint from the package MASS ( $\mathrm{R}$ Development Core Team, 2009).

The $p$ factor, defined as the average fraction of TTSW that can be depleted from the root zone before reduction in transpiration occurs, was calculated by the following equation:

$$
p=1-\text { FTSW } \text { for NTR }=0.95
$$

In this study, the same approach used by Sadras and Milroy (1996) was assumed, which considers that the $p$ factor occurs when NTR was equal to 0.95 .

\section{Results and Discussion}

For the $\mathrm{V}$ experiment, the duration of the stress treatment was 19 and 12 days for the first and second sowing dates, respectively. Basically, there was no difference among cultivars for both sowing dates. For the $\mathrm{R}$ experiment, the duration of stress treatment for cultivars BRS Primavera, BRS Soberana and Douradão were nine and seven days and for BRSMG Curinga seven and six days, for the first and second sowing dates, respectively. The number of observed data was larger for the vegetative phase (Figure 2a, c and e, g) due to the longer duration of the $\mathrm{V}$ experiment in this phase for all cultivars, compared to the $\mathrm{R}$ experiment duration. The reason was that in the vegetative phase, the amount of above ground biomass is less than in the reproductive phase. The values of the parameters of the empirical model are shown in Table 1 and they were significant at the 5\% for all cultivars in both phases, with exception of cultivar BRSMG Curinga, whose value of the a parameter in the reproductive phase was significant at the $10 \%$ probability level. This parameter is related to the curve deflection. This was responsible for the higher standard errors (Table 1) and confidence intervals (Figure 2).

The values of the a empiric parameter were lower in the vegetative phase (Table 1) for all the cultivars, except BRS Primavera. For this cultivar, the a parameter showed the highest standard error (Table 1) probably due to some observed data trend from sowing $(8 / 27)$ (Figure 2c). Based on the a parameter confidence interval at the $95 \%$ probability level, there was a difference between the vegetative and reproductive phases for cultivars Douradão and BRSMG Curinga (Figure 3a). The $b$ empirical parameter (equation 2) is related to the inclination of the linear model phase. For all cultivars, the values of $b$ were lower in the vegetative phase compared to reproductive phase. Based on the $b$ parameter confidence interval at $95 \%$ probability (Figure $3 b$ ), there was no difference between vegetative and reproductive phases for all evaluated cultivars. However, the variance was not heterogeneous for all adjusted models, and usually this will not influence parameter estimates, but may result in a misleading conclusion on the confidence intervals (Carroll and Ruppert, 1988).

This study was conducted to evaluate the adaptive responses of four upland rice cultivars to water stress in different phases of development, i.e. vegetative and reproductive. The hypothesis was that physiological plant process, such as transpiration, is influenced by the progressive water deficit and that there are genotypic differences in the adaptation of upland rice genotypes to water stress in different phenological phases. This physiological process is inhibited when the available soil moisture for transpiration (FTSW) decreases to values in the range of $40-50 \%$, with a trend that appears to be consistent across a wide range of environments and genotypes (Sadras and Milroy, 1996). There were differences in the plant adaptation for water stress between the veg- 

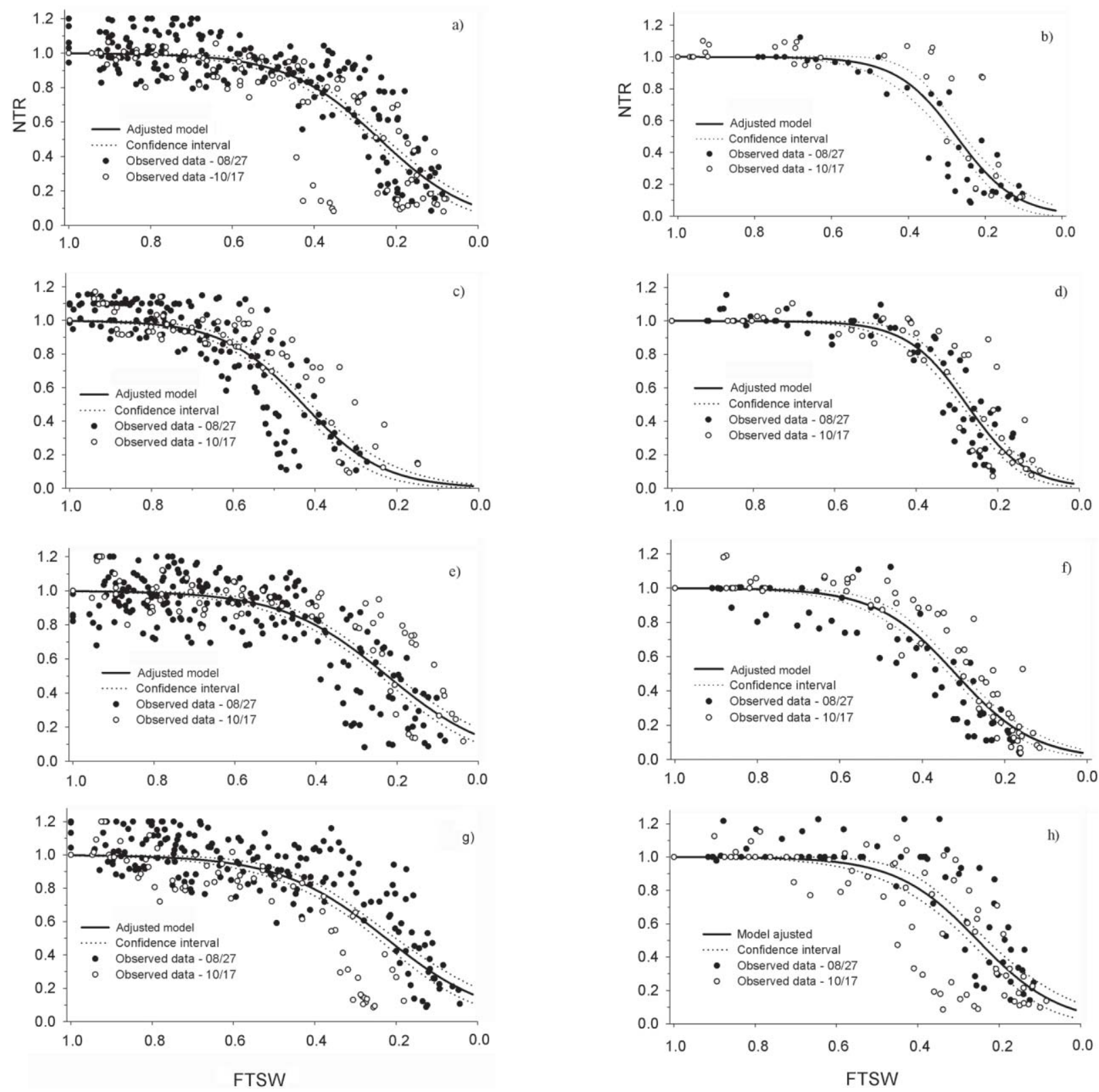

Figure 2 - Relationship between the normalized transpiration rate (NTR) and the fraction of transpirable soil water (FTSW) and confidence interval for upland rice cultivars BRSMG Curinga a) vegetative phase, b) reproductive phase; BRS Primavera c) vegetative phase, d) reproductive phase; Douradão e) vegetative phase f) reproductive phase and BRS Soberana g) vegetative phase, $\mathrm{h}$ ) reproductive phase.

etative and reproductive phases (Figure 2). For the modern cultivars, BRS Primavera, BRS Soberana and BRSMG Curinga, the $p$ factor was lower for the vegetative than for the reproductive phase (Table 2). Only the traditional cultivar, Douradão, had the same $p$ factor for the vegetative and reproductive phases. Wopereis et al. (1996) applied water stress three weeks after transplanting for flooded rice and showed that water deficit responses in young plants occurred at a lower soil water content (higher value of $p$ factor) than in older plants. These results do not agree with the results obtained in this study. However, we applied the water stress at \pm stage V5 and, in our opinion a lower $p$ factor together a lower inclination (lower $b$ parameter - Table 1) can be considered a better adaptation or growth optimization for an unfavorable condition, such as drought. Plants generally limit the leave number and area in response to water stress just to cut down the water budget at cost of yield loss (Schuppler et al., 1998). In the vegetative phase, the amount of water used is directly proportional to transpiration and thus dry matter production. When soil moisture begins to decline, the most effective response of the plant is to reduce the transpiration. The first signs of declining soil water are leaf rolling and sto- 
Table 1 - Empirical $a$ and $b$ model parameters for vegetative and reproductive phases for cultivars Douradão, BRS Primavera, BRS Soberana, and BRSMG Curinga.

\begin{tabular}{lccccc}
\hline \multirow{2}{*}{ Cultivar } & \multicolumn{2}{c}{ Vegetative phase } & & \multicolumn{2}{c}{ Reproductive phase } \\
\cline { 2 - 3 } \cline { 5 - 6 } BRSMG Curinga & $\mathrm{a}$ & $\mathrm{SE}$ & & $\mathrm{a}$ & $\mathrm{SE}$ \\
BRS Primavera & $8.24^{*}$ & 1.49 & & $34.44^{* * *}$ & 17.71 \\
Douradão & $81.65^{*}$ & 33.38 & & $43.13^{*}$ & 15.97 \\
BRS Soberana & $5.66^{*}$ & 0.97 & & $28.08^{*}$ & 7.97 \\
\hline Cultivar & $5.63^{*}$ & 1.13 & & $12.47^{*}$ & 4.21 \\
\hline BRSMG Curinga & $\mathrm{b}$ & $\mathrm{SE}$ & & $\mathrm{b}$ & $\mathrm{SE}$ \\
\hline BRS Primavera & $8.78^{*}$ & 0.64 & & $12.88^{*}$ & 1.93 \\
Douradão & $10.26^{*}$ & 0.84 & & $13.62^{*}$ & 1.34 \\
BRS Soberana & $7.75^{*}$ & 0.59 & & $10.45^{*}$ & 0.89 \\
\hline
\end{tabular}

*significant to $5 \%$; **significant to $10 \% ; \mathrm{SE}=$ standard error.

Table 2 - The $p$ factor at 0.95 normalized transpiration rate (NTR) for vegetative and reproductive phases of cultivars Douradão, BRS Primavera, BRS Soberana, and BRSMG Curinga.

\begin{tabular}{lcc}
\hline Cultivar & \multicolumn{2}{c}{$p$ factor } \\
\hline & Vegetative phase & Reproductive phase \\
\hline BRSMG Curinga & 0.42 & 0.49 \\
BRS Primavera & 0.28 & 0.50 \\
Douradão & 0.39 & 0.39 \\
BRS Soberana & 0.39 & 0.45 \\
\hline
\end{tabular}

mata closing (Fisher and Fukai, 2003). Based on the results obtained in this study ( $p$ factor, Table 2), we assume, for modern cultivars, that the first signs, leaf rolling and stomata closing, are the basic mechanism for reducing the impact of drought (Bernier et al., 2008), and are induced first in the vegetative phase than in the reproductive phase.

Lilley and Fukai (1994), Boonjung and Fukai (1996), and Fisher and Fukai (2003) used modern cultivars and reported that the water stress effects on the vegetative phase are less damaging in yield than in the reproductive phase. BRS Primavera, BRS Soberana and BRSMG Curinga are considered new and they were released in 1997, 2003/2004 and 2005, respectively. One hypothesis to explain the observed variation of the $p$ factor for the vegetative and reproductive phases for these cultivars is that these cultivars, based on osmotic adjustment, are not able to maintain the leaf turgor in the reproductive phase supporting stomatal conductance under lower leaf water status. According to Blum (2009), it is defined as effective use of water and is the major engine for agronomic or genetic enhancement of crop production. Genotypic variation expressed as osmotic adjustment and leaf water potential has been reported in rice cultivars with diverse genetic backgrounds (O'Toole and Moya, 1978; Lilley and Lodlow, 1996) and under water deficits

\section{a) Cultivar Phase Parameter a}

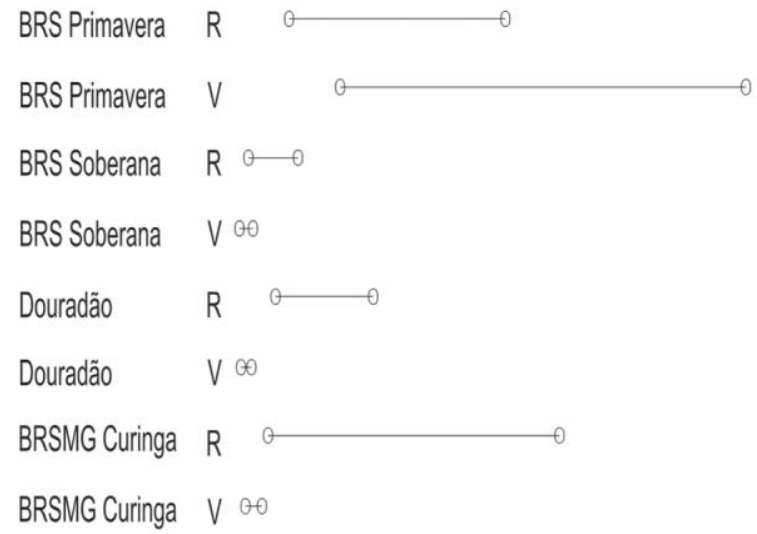

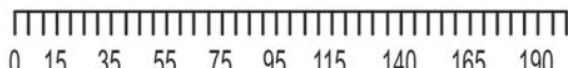

$\begin{array}{llllllllll}0 & 15 & 35 & 55 & 75 & 95 & 115 & 140 & 165 & 190\end{array}$

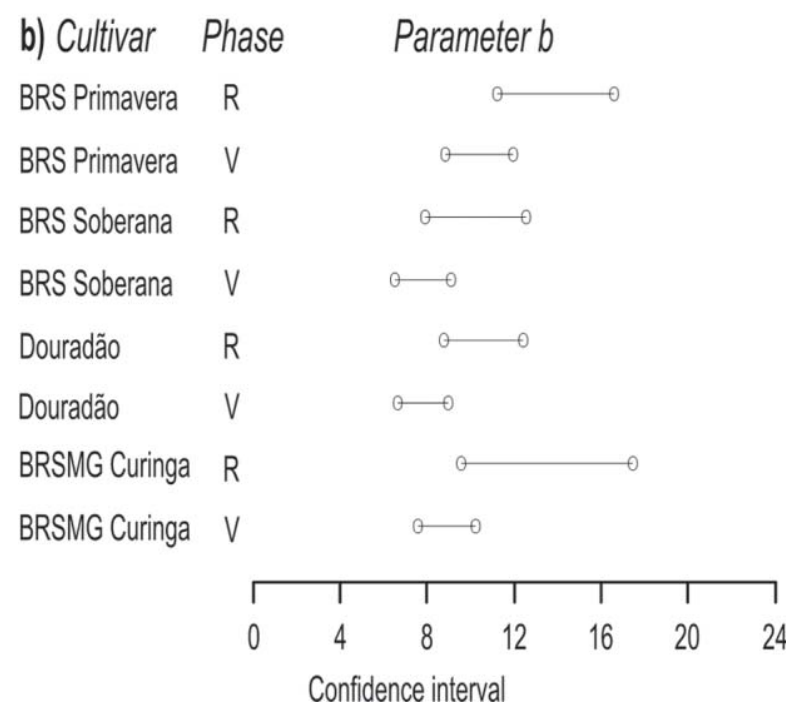

Figure 3 - Confidence intervals for empiric model parameters a) $a$ and b) $b$ for the vegetative $(\mathrm{V})$ and reproductive (R) development phases for cultivars BRS Primavera, BRS Soberana, BRSMG Curinga, and Douradão. 
for both vegetative and flowering stages (Jongdee et al., 2002). For upland rice breeding strategy this is adopted since 1980 's, and the selection is focused on high yield potential in targeting the favorable savanna areas where drought periods are not expected (Pinheiro et al., 2006). Nevertheless, for the traditional cultivar, the $p$ factor was the same in both phases. This cultivar was released in 1977 (Anonymous, 1989). Probably, the traditional cultivar studied here did not develop the mechanism described above for modern cultivars in the reproductive phase, showing only the basic mechanism for reducing the impact of water stress, early stomatal closure at the beginning of a period of water deficit (Bernier et al., 2008). These cultivars are better adapted to express their potential yield in the most favorable areas considering low intensity and occurrence of water deficit and the traditional cultivar is enable to better support adverse conditions of water deficit. It can be concluded that there is need to precisely characterize the drought patterns in target population environments (TPEs), instead of searching for global solutions for a generic "drought" (Heinemann et al., 2008). The precise characterization of drought patterns for a TPE can determine in which phase there is more probability to occur a water deficit, as well as its intensity. This information can focus breeding programs to improve drought tolerance in modern upland rice cultivars.

\section{References}

Anonymous. 1989. Douradão: new upland rice cultivar for Minas Gerais. EPAMIG, Belo Horizonte, MG, Brazil. Available at: http://www.cnpaf.embrapa.br/arroz/folderes/douradao.pdf. [Accessed May 25, 2010]. (in Portuguese).

Bernier, J.; Atlin, G.N.; Serraj, R.; Kumar, A.; Spaner, D. 2008. Review: breeding upland rice for drought resistance. Journal of the Science of Food and Agriculture 88: 927-939.

Bhatnagar-Mathur, P.; Devi, M.J.; Reddy, S.D.; Lavanya, M.; Vadez, V.; Serraj, R.; Yamaguchi-Shinozaki, K.; Sharma, K.K. 2007. Stress-inducible expression of DREB1A in transgenic peanut (Arachis hypogea L.) increases transpiration efficiency under water-limiting conditions. Plant Cell Reports 26: 2071-2082.

Blum, A. 2009. Effective use of water (EUW) and not water-use efficiency (WUE) is the target of crop yield improvement under drought stress. Field Crops Research 112: 119-123.

Boonjung, H.; Fukai, S. 1996. Effect of soil water deficit at conditions. 2. Phenology, biomass production, and yield. Field Crops Research 48: 47-55.

Breseghello, F.; Guimarães, C.M.; Pinheiro, B.S. 2008. Recent efforts to improve drought resistance of rice in Brazil. p. 113122. In: Serraj, R.; Bennett, J.; Hardy, B., eds. Drought frontiers in rice: crop improvement for increased rainfed production. International Rice Research Institute, Los Baños, Philippines.

Carroll, R.J.; Ruppert, D. 1988. Transformation and Weighting in Regression. Chapman and Hall, New York, NY, USA.

Counce, P.A.; Keisling, T.C.; Mitchel, A.J. 2000. A uniform, objective, and adaptive system for expressing rice development. Crop Science 40: 436-443.

Fisher, K.S.; Fukai, S. 2003. How rice responds to drought. p. 3236. In: Fisher, K.S.; Lattife, R.; Fukai, S.; Atlin, G.; Hardy, B., eds. Breeding rice for drought-prone enviroments. International Rice Research Institute, Los Banõs, Philippines.

Jongdee, B.; Fukai, S.; Cooper, M. 2002. Leaf water potential and osmotic adjustment as physiological traits to improve drought tolerance in rice. Field Crop Research 76: 153-163.
Heinemann, A.B.; Dingkuhn, M.; Luquet, D.; Combres, J.C.; Chapman, S. 2008. Characterization of drought stress environments for upland rice and maize in central Brazil. Euphytica 162: 395-410.

Heinemann, A.B.; Silva, S.C.; Lopes Júnior, S.; Amorim, A.O.; Andrade, C.L.T.; Bastos, E.A.; Paz, R.L. 2007. Climatic characteristics of the municipalities of Santo Antônio de Goiás (GO), Porangatu (GO), Janaúba (MG), Sete Lagoas (MG), Parnaíba (IP) and Teresina (PI), Brazil. Embrapa Arroz e Feijão, Santo Antônio de Goiás, GO, Brazil. Available at: http:// www.cnpaf.embrapa.br/publicacao/seriedocumentos/ doc_214.pdf. [Accessed May 25, 2010]. (in Portuguese).

Heinemann, A.B.; Stone, L.F; Fageria, N.K.; Castro, L.M. de. 2009. Evaluation of physiological traits in upland rice for adaptation to no-tillage system. Brazilian Journal of Plant Physiology 21: 113-122.

Hufstetler, E.V.; Boerma, H.R.; Carter, T.E.; Earl, H.J. 2007. Genotypic variation for three physiological traits affecting drought tolerance in soybean. Crop Science 47: 25-35.

Kholová, J.; Hash, C.T.; Kakkera, A.; Koová, M.; Vadez, V. 2010. Constitutive water-conserving mechanisms are correlated with the terminal drought tolerance of pearl millet [Pennisetum glaucum (L.) R. Br.]. Journal of Experimental Botany 61: 369-377.

Kumar, A.; Bernier, J.; Verulkar, S.; Lafitte, H.R.; Atlin, G.N. 2008. Breeding for drought tolerance: direct selection for yield, response to selection and use of drought-tolerant donors in upland and lowland-adapted populations. Field Crops Research 107: 221-231.

Lilley, J.M.; Lodlow, M.M. 1996. Expresion of osmotic adjustment and dehydration tolerance in diverse rice lines. Field Crop Research 48:185-197.

Lilley, J.M.; Fukai, S. 1994. Effect of timing and severity of water deficit on four diverse rice cultivars. III. Phenological development, crop growth and grain yield. Field Crops Research 37: 225-234.

Muchow, R.C.; Sinclair, T.R. 1991. Water deficit effects on maize yields modeled under current and "greenhouse" climates. Agronomy Journal 83: 1052-1059.

O'Toole, J.C.; Moya, T.B. 1978. Genetic variation in maintenance of leaf water potencial in Rice. Crop Science 18: 873-876.

Pantuwan, G.; Fukai, S.; Cooper, M.; Rajatasereekul, S.; O’Toole, J.C. 2002. Yield response of rice (Oryza sativa L.) genotypes to drought under rainfed lowland. 3. Plant factors contributing to drought resistance. Field Crops Research 73: 181-200.

Pinheiro, B.S.; Castro, E.M.; Guimarães, C.M. 2006. Sustainability and profitability of aerobic rice production in Brazil. Field Crops Research 97: 34-42.

R Development Core Team. 2009. R: A Language and Environment for Statistical Computing. R Foundation for Statistical Computing, Vienna, Austria. Available at: http://www.Rproject.org. [Accessed May 25, 2010].

Ray, J.D.; Sinclair, T.R. 1997. Stomatal closure of maize hybrids in response to soil drying. Crop Science 37: 803-807.

Sadras, V.O.; Milroy, S.P. 1996. Soil-water thresholds for the responses of leaf expansion and gas exchange: A review. Field Crops Research 47: 253-266.

Schuppler, U.; He, P.H.; John, P.C.L.; Munns, R. 1998. Effects of water stress on cell division and cell-division-cycle-2-like cell cycle kinase activity in wheat leaves. Plant Physiology 117: 667-678.

Serraj, R.; Dimayuga, D.; Gowda, V.; Guan, Y.; He, H.; Impa, S.; Liu, D.C.; Mabesa, R.C.; Sellamuthu, R.; Torres, R. 2008. Drought-resistant rice: physiological framework for an integrated research strategy. p. 139-170. In: Serraj, R.; Bennett, J.; Hardy, B., eds. Drought frontiers in rice: crop improvement for increased rainfed production. International Rice Research Institute, Los Baños, Philippines.

Serraj, R.; Kumar, A.; McNally, K.L.; Slamet-Loedin, I.; Bruskiewich, R.; Mauleon, R.; Cairns, J.K.; Hijmans, R.J. 2009. Improvement of drought resistance in rice. Advances in Agronomy 103: 41-99. 
Sinclair, T.R.; Ludlow, M.M. 1986. Influence of soil water supply on the plant water balance of four tropical grain legumes. Australian Journal of Plant Physiology 13: 329-341.

Sinclair, T.R.; Zwieniecki, M.A.; Holbrook, N.M. 2008. Low leaf hydraulic conductance associated with drought tolerance in soybean. Physiologia Plantarum 132: 446-451.

Turner, N.C.; Wright, G.C.; Siddique, K.H.M. 2000. Adaptation of grain legumes (Pulses) to water-limited environments. Advances in Agronomy 71: 193-231.

Vadez, V.; Sinclair, T.R. 2001. Leaf ureide degradation and $\mathrm{N}_{2}$ fixation tolerance to water deficit in soybean. Journal of Experimental Botany 52: 153-159.
Wahbi, A.; Sinclair, T.R. 2007. Transpiration response of Arabidopsis, maize, and soybean to drying of artificial and mineral soil. Environmental and Experimental Botany 59: 188192.

Wopereis, M.C.S.; Kropff, M.J.; Maligaya, A.R.; Tuong, T.P. 1996. Drought-stress responses of two lowland rice cultivars to soil water status. Field Crop Research 46: 21-39.

Received July 14, 2009

Accepted July 13, 2010 